\title{
ИПОСТАСИ ХУДОЖЕСТВЕННОГО ПРОСТРАНСТВА: НОСТАЛЬГИЯ И ВООБРАЖЕНИЕ (НА ПРИМЕРЕ ПОВЕСТИ АЛЕКСАНДРА ПОТЕМКИНА КАБАЛА)
}

\author{
HYPOSTASES OF ARTISTIC SPACE: NOSTALGIA AND IMAGINATION \\ (ON THE EXAMPLE OF THE STORY KABALA \\ BY ALEXANDER POTYOMKIN)
}

LESŁAWA KORENOWSKA

\begin{abstract}
Aвstract. Artistic space, presented in the story Kabala by A. Potyomkin, can be seen in various hypostases. The real, ethereal and ill-fated areas of the imagination of the main character connect with his opium dependence. Parfirchikov's imagination is tightly connected with nostalgia, which manifests itself in the escape from the real world into the dreamed space of his inner world. Every character's transformation from one space into another takes place after the dose of drug is taken by him.
\end{abstract}

Keywords: hypostases, artistic space, inner world, nostalgia, imagination

Lesława Korenowska, Uniwersytet Pedagogiczny im. Komisji Edukacji Narodowej w Krakowie, Kraków - Polska, malekor@op.pl

ORCID ID: 0000-0003-1372-0667

Художественное пространство в произведении искусства всегда занимало и занимает одно из важных мест. Этому феномену посвящены исследования таких ученых, как Дмитрий Лихачев, Юрий Лотман, Андрей Есин, Ефим Эткинд, Вера Савельева, Юлиана Пыхтина и многих других. Следует заметить, что пространство как фон развёртывания сюжетных событий, как сюжетная организация текста, как внутренний (психологический и речевой) мир героя, а также как язык художественного пространства описаны довольно широко и объёмно [Лихачев 1970; Эткинд 1998; Савельева 1999; Есин 2011; Пыхтина 2014]. Однако пространству внутренней структуры героя, которое базируется на мотивах или импульсах, побуждающих персонажа к тому или иному действию, к „озвучиванию” внутреннего монолога, к экспликации наблюдений над окружающей природой или рассуждений философского, нравственного или бытового характера, посвящено, как оказалось, не так уж много работ.

Прежде чем перейти к рассмотрению ипостасей художественного пространства на примере повести Александра Потемкина Кабала, необ- 
ходимо сосредоточиться на таких понятиях, как ностальгия и воображение и попытаться раскрыть смысл, имплицированный в их содержании.

B XIX веке ностальгией (от гр. nostos - возвращение, algia - боль) называли такие психофизические состояния, как меланхолия, анорексия, а также самоубийство. В Stowniku poprawnej polszczyzny этот термин получил определение тоски по родному дому, отчизне; боли, которая появляется во время длительного пребывания на чужбине; желания поскорее вернуться на родную землю [Markowski 2003: 522]. Тот факт, что исследователи начали описывать данный феномен, доказывает, что в мире появился новый способ переживаний либо новый способ мышления о существующем переживании, что, в свою очередь, свидетельствует о связи ностальгии с современностью. Важно отметить, что с распространением этого термина существенно изменилось его значение. Под воздействием романтизма наступил переход от использования „ностальгии” как термина, описывающего физиологические недомогания, до обозначения им психического состояния индивидуума, страдающего депрессией, связанной с разлукой с родной землей или же длительным пребыванием на чужбине. Ностальгия начала приобретать не только пространственное измерение, но и темпоральное.

Следующим этапом эволюции значения данного термина стало его употребление уже не только в аспекте проблем отдельной личности, но и в целостном контексте „болезни общества” [Steward 1993: 23]. Кроме того, ностальгия рассматривалась как регрессивное, иррациональное явление, на которое накладывались следующие компоненты: фальсификация истории, проявления сентиментализма, отсутствие объективизма и недоверия к собственному опыту. Ностальгию начинают использовать для дескрипции общественных групп, которые плохо ассимилируются в постоянно меняющемся мире; она становится, по мнению Маркоса Натали, определением тех, кто стал маргиналом современности [Natali 2004: 18].

В настоящее время известным критиком данного феномена является Сьюзен Стюварт, которая рассматривает ностальгию как бегство от действительности к воображаемому идеализированному прошлому прошлому, которого в другой форме, чем наррация, не существовало. Прошлое отсутствует, а это значит, что „точкой желания ностальгика становится пустота, которая в действительности и является механизмом, генерирующим желание, т.е. ностальгия становится желанием самого желания" [Steward 1993: 23]. Однако в последнее время многие критики считают такой подход слишком упрощенным, поэтому выдвигается тезис „множества ностальгий”, что позволяет судить о возможности существования положительных аспектов ностальгии [Steward 1993: 
20]. Светлана Бойм считает, что ностальгия может стать обращением к прошлому, в котором видится причина отказа от действительности. Предметом тоски становятся потерянная жизненная стабильность, медленный бег времени, не ускоренный избытком информации, поступающей с разных уголков мира, - иными словами, все то, что запрещает современность. С одной стороны, можно утверждать, что ностальгия „не является врагом современности, а только ее составной частью" [Бойм 2002: 299]. С другой же - является феноменом „улетучивающегося и недостижимого" nostos - объекта тоски, метафорического дома, который перестал существовать, а может быть, и не существовал никогда. Если же algia - боль - несет в себе соединяющий потенциал, то nostos как раз и разделяет людей, которыми овладела тоска, на своих и чужих, согласно представлению о потерянном объекте. Ностальгия стала определением не только тоски по прошлому, которое не имело места, но и по параллельным дорогам жизненного выбора, неосуществленным возможностями, которые в результате наших решений, независимо от хода истории, стали критерием условного наклонения [Бойм 2002: 303].

Английские исследователи Микаэль Пикеринг и Эмили Кейтли выдвигают мысль о том, что результатом признания этого феномена как оппозиции к прогрессу стала „идентификация его с ориентацией на прошлое, с дефетистическим отношением к действительности и будущему, со стремлением осуществить недостижимое, с удовлетворением неудовлетворенного" [Pickering, Keightley 2006: 920]. Такой подход разрешает проблему аутентичного неудовлетворения и сожаления об изменениях, которые принесло время, но также игнорирует вопрос возможностями активного сотрудничества прошлого с настоящим и будущим. Отсюда напрашивается вывод, что существует необходимость изменить взгляд, согласно которому ностальгия представлена только лишь как элемент амнезийной культуры, проявляющийся в таких массовых тенденциях, как поверхностный стиль, стереотип, кич; возникла потребность поиска разных типов отношений ностальгии к прошлому, видов сотрудничества с ним и выхода на новые характеристики данного феномена, касающиеся психического состояния личности [Pickering, Keightley 2006: 924].

Почему же ностальгию можно поставить в один ряд с воображением (как и с меланхолией)? Бесспорно, воображение является составной частью онтологии ностальгии, поскольку этот термин обладает способностью создавать определенные образы, представления, некоторые идеи и искусно манипулировать ими. Воображение играет доминирующую роль в таких психологических процессах, как творчество, визуализация, моделирование, память, принимая во внимание всякий процесс, который протекает „в образах” [Сартр 2001: 43]. Следует добавить, что во- 
ображение способно пребывать в трех временных измерениях, рисуя в них как реальные, так и ирреальные образы. Но то, что объединяет ностальгию и воображение, это процесс мышления, память, фантазия и зачастую желание создать такое пространство, в котором будут царить желаемое и неосуществимое в действительности, мир комфорта и радости, т.е. то, чего нет в реальности, причем этот мир благодаря заостренным органам чувств воспринимается как действительно существующий - в отличие от большинства образов и мыслей.

Перенесем вышеизложенные мысли на конкретные примеры из повести Потемкина Кабала (2008-2009) с целью эксплицировать ипостаси художественного пространства в онтологическом наполнении ностальгии и воображения.

Повесть Кабала - это интересный жанровый эксперимент, тяготеющий к психологической прозе, немного к приключенческой и в некоторой степени к фантастике, маркированный как повесть „для самого себя", чтение которой вызывает у читателей предвкушение вхождения в область интимности автора. Объединяющий двенадцать глав мотив это мир виртуальности, достигаемый при помощи употребления наркотика. Повесть в большей части текстуальной фактуры представляет поток сознания молодого человека, пребывающего в трансе опийного опьянения, а также его идейные споры с подобными ему субъектами.

Главный герой повести Петр Петрович Парфирчиков представлен в нескольких пространственных измерениях. В начале повести это обеспеченный тридцатилетний мужчина, работающий в престижном московском офисе, обладающий многими эксклюзивными вещами, посещающий модные клубы и т.д. В следующих главах мы видим совершенно другого Парфирчикова: закоренелого наркомана, отдавшегося во властные руки маковой головки. Именно как человек, находящийся на маргинесе общества, Парфирчиков в своих наркотических фантасмагориях рисует несколько ипостасей пространства, которые рождаются в его больном воображении. Оригинальность этих ипостасей или моделей проявляется в сложной комбинации пространственных образов в рамках одной текстовой фактуры и в конструировании я-пространства, находящегося то в наркотическом дурмане, то в наркотическом голоде, а то в мимолетных просветах между этими двумя состояниями. То, что объединяет эти разнородные пространства, это воображение и ностальгия.

Проследим более детально локусы „пребывания” ностальгического воображения Петра Петровича Парфирчикова. Наблюдая за своими соотечественниками, один из героев повести, Григорий Семенович Помешкин, служащий дорожного ведомства, приходит к выводу, что это 
лишь кажется, что все люди живут в одной стране. „На самом деле мы существуем на территории одного и того же государства, но в тысячах самых разных миров" [Потемкин 2011] Мир как пространство пребывания собственных мыслей, желаний, видений, иллюзий, потребностей у каждого свой. И то, чем наполнены эти воображаемые пространства, позволяет судить о содержательности внутреннего мира личности. Идея абстрагироваться от общества, бежать из Москвы и „найти себя в другом формате” приводит Парфирчикова в городок Кан Красноярского края.

Свою цель главный герой определил следующим образом: „Я Х хотел реализоваться в беспокойных мечтах, в играх воспаленного сознания" [Потемкин 2011]. Поддаваясь воздействию опия, „из жалкого болезненного человечка Петр Петрович превращается в действующий вулкан фантазий”. Оказывается, что маковая головка может „слепить из тебя того, кого ты сам захочешь". Особенно яркие картины передислокаций в пространстве являются перед героем в поезде, который увозит его в городок мечты и исполнения заветного желания - выращивать на огромном земельном участке море маковых головок. В дороге Петр Петрович знакомится с профессором Евгением Кошмаровым, „модулятором нового времени". Последний открывает герою идею сборной пилюли четырех наций, некий этнический коктейль, способный перевоплотить обыкновенного русского человека в более совершенную личность, подмешивающий в кровь соотечественников „этнический купаж: ансамбль немецкой, китайской, еврейской и грузинской генетики". Парфирчиков соглашается на эксперимент и получает инъекцию, после которой по-своему начинает „наблюдать за реальностью из своего ирреального гнездышка".

Первая модель воображаемого пространства, которую условно можно назвать „территориально одухотворенное пространство”, связана с Москвой. Перед нами вырисовывается картина города, в котором наблюдается небывалый душевный национальный подъем и „волшебной силой навсегда отбрасывается потребительская ментальность” . Главным становится не то, чем ты обладаешь, а то, „о чем ты думаешь, чем заняты мозги, что грандиозное создаешь, о чем вдохновенно мечтаешь!". Иллюзия идеального общества представлена как плод воображения, стимулированного нанапилюлей. Выход из наркотического состояния вызывает у Парфирчикова „страстное желание как можно быстрее переместить себя из реальности в фантазии взлохмаченного воображения". Для этого необходимо принять определенную дозу кукнаря, способного „расширять границы сознания" . Ведь недаром кукнарь, согласно мнению героя это „билет в воображаемый мир, средство, способное ускорить бегство от действительности". 
Появляется картина, представляющая иную ипостась пространства „неограниченную”. На этот раз это авиакосмический салон „МАКС2008". Парфирчиков признается:

Я хотел значительно большего - чувствовать его (мир - Л. К.), размышлять над ним, совершенствовать его. Ведь для того, чтобы сесть на маковую головку, необходимо иметь богатейшую душу и интеллект с ироническим окрасом. Нынешняя моя жизнь обращена вовнутрь - на фантастическую сцену подсознания [Потемкин 2011].

Воображаемое пространство позволяет Петру Петровичу настолько сильно оторваться от окружающей действительности и перенестись в иной мир, дающий ему неограниченные возможности фантазирования, осуществления самых невероятных желаний, представления себя в разных ролях, причем без каких-либо усилий, условий, ответственности и т.п., что улетучивание радужного состояния вызывает у героя только одну потребность - как можно скорее принять ложечку кукнаря.

Автор очень верно описывает моменты, в которых рушится мир воображения героя, т.е. время, когда прекращается действие наркотика. Болезненная зависимость от наркотического средства передается ностальгическим признанием Парфирчикова:

Воображение тускнело, память перестала пульсировать воспоминаниями, а разум угасал. Надо было освежиться, взбодриться, всколыхнуть себя фантасмагориями. Без них жить уже совершенно невозможно. Мак крепенький, извращает разум, заполняет химерами сознание! [Потемкин 2011].

Ностальгическая боль и желание вернутся в рай своего воображения стимулирует каждый шаг главного героя.

Следующая ипостась мнимого пространства героя - это тюрьма, в которой тот пребывает как арестант и как начальник пенитенциарного заведения. Эту модель определим как „закрытое” пространство. Свое пребывание в месте заключения Петр Петрович подытоживает следующим образом: „Вечная опийная кабала”. Куда бы воображение ни переносило Парфирчикова, он всегда находится под воздействием опия. Только в состоянии реально принятой дозы наркотика герой способен расширять пространство своего воображения, рисуя в нем картины своих тайных желаний.

Модель „реального” пространства вырисовывается в Кане, куда Петр Петрович прибывает на постоянное место жительства. „Повседневные картины стали занимать воображение. Я вчера совсем неплохо потрудился. Четверть поля вскопал и засеял кашкарским маком" [Потемкин 2011]. 
Кажется, герой осуществил свою мечту. Пребывание в городке дает ему возможность развивать мир фантазии, оставляя за порогом сознания „фальшивый окружающий мир”. Для Парфирчикова Кан, его маковое поле, новый друг-наркоман Григорий Семонович Помешкин становятся реальностью, которая, как ни парадоксально, соткана из нитей ностальгического воображения. Существование в конкретном пространственном локусе, наполненном сказочными возможностями употребления неограниченного количества опия, стирает грань между „смыслами фантазии и блеклой реальностью". Есть только пространство воображения, причем ощущаемое и переживаемое Петром Петровичем настолько реально, что все вокруг него теряет смысл, облекается в наркотический дурман блаженства.

Реальность мешается с наваждением. Пытаешься ощутить окружающий мир, касаешься его ладонью, ноги упираются в твердь, нос впитывает удивительные ароматы, взгляд скользит, высматривая приятные очертания, слух ловит ласкающую сердце музыку бытия [Потемкин 2011].

Художественно убедительно и патетически описаны автором повести минуты забвенья Парфирчикова. В больном воображении Парфирчикова даже появляется совершенно чуждое ему и неожиданное желание - завести ребенка с хромой продавщицей. Пространство, мир, реальность перестают управляться здравым рассудком Парфирчикова - они полностью подвластны его „взбудораженному маком воображению”. Нет ничего удивительного в признании Петра Петровича: „Я дал клятву, ни при каких условиях не возвращаться в реальность, оставаться лишь в чудесном мире воображения" [Потемкин 2011]. Почему? Ответ прост: ностальгия как боль по желаемому и потерянному растворяется в воображении Петра Петровича, можно даже сказать, исчезает в его сознании именно благодаря приобретению счастья в виде осуществления заветной мечты, - и все это происходит после принятия дозы кукнаря. Воображение поглощает ностальгию, давая ей совершенно другое наполнение, являющееся герою новой жизнью, миром, реальностью. Но, к сожалению, счастье забвения слишком кратковременно. Наркотический взлет сознания не воспринимается героем как трагедия или как медленная смерть.

Подводя итог, следует заметить, что ностальгия и воображение являются цементирующими элементами в рассмотренном произведении. Ностальгическое настроение рождает мощные импульсы, способные привести в движение воображение, которое, в свою очередь, рисует разные ипостаси пространства. Писатель выступает здесь в нескольких ролях: как философ, психолог, этнолог, социолог. Он очень искусно по- 
гружает размышления личного характера (о поисках человеком самого себя, об осуществлении своей мечты, о слабости души и тела, о силе воображения, заставляющего исчезнуть ностальгическую боль) в сюрреалистические пласты описания быта человека, зависящего от наркотика. Выводы же предлагается сделать самому читателю.

Проблемы, затронутые в повести Александра Потемкина Кабала подтверждают мысль о том, что человеческие страсти, желания, стремления зачастую находятся вне времени и вне пространства. Ностальгия и воображение - две мощные силы, способные будоражить ум и чувства человека, влиять на состояние сознания и изменять его. Еще в 60-е годы прошлого века возник огромный интерес к воздействию наркотиков и галлюциногенов на состояние человека. Две научные дисциплины психология и антропология - вплотную подошли к разрешению этой проблемы. Но то, что словесное искусство также занялось описанием разных аспектов данной проблемы, свидетельствует о ее значимости и актуальности.

\section{Библиография}

Бойм С. 2002. Общие места. Мифология повседневной жизни, Москва: Новое литературное обозрение.

Есин А. Б. 2011. Психологизм русской классической литературы, Москва: Флинта.

Лихачев Д. С. 1970. Человек В литературе древней Руси, Москва: Наука.

Потемкин А. 2011. Кабала, электронный ресурс: http://loveread.ec/read_book. php?id=38231\&p=2 (доступ 17.03.2017).

Пыхтина Ю. 2014. Структура художественного пространства В повести А. П. Потемкина „Я", электронный ресурс: http://gisap.eu/ru/node/22402 (доступ 17.06.2017).

Савельева В. В. 1999. Художественная антропология, Алматы: Алматинский Государственный университет им. Абая.

Сартр Ж.-П. 2001. Воображаемое. Феноменологическая психология воображения, перевод с фр. М. Бекетовой, Санкт-Петербург: Наука.

Эткинд Е. Г. 1998. Внутренний человек и внешняя речъ, Москва: Языки русской культуры.

Markowski A. (red.) 2003. Stownik poprawnej polszczyzny PWN, Warszawa: Wydawnictwo Naukowe PWN.

Natali M. P. 2004. History and the Politics of Nostalgia, "Iowa Journal of Cultural Studies”, № 5, электронный ресурс: http:/ / ir.uiowa.edu/cgi/viewcontent.cgi?article=1113\& context=ijcs (доступ 27.07.2017).

Pickering M., Keightley E. 2006, The Modalities of Nostalgia, „Current Sociology”, т. 54, № 6.

Stewart S. 1993. On Longing: Narratives of the Miniature, the Gigantic, the Souvenir. The Collection, Durham-London: Duke University Press. 